\title{
Efficiency of the Black Foreign Exchange Market
}

\author{
Ali Farhan Chaudhry ${ }^{1}$, Mian Muhammd Hanif ${ }^{2}$, Sameera Hassan ${ }^{1} \&$ Muhammad Irfan Chani ${ }^{3}$ \\ ${ }^{1}$ Ted Rogers School of Management, Ryerson University, Toronto, Canada \\ ${ }^{2}$ National College of Business Administration \& Economics, Gulberg III, Lahore, Pakistan \\ ${ }^{3}$ COMSATS Institute of Information Technology, Pir Murad, Vehari, Pakistan \\ Correspondence: Sameera Hassan, Ted Rogers School of Management, Ryerson University, 55 Dundas St. West, \\ Toronto, ON M5G 2C3, Canada. E-mail: sameera.syedhassan@ gmail.com
}

Received: April 15, 2018

doi:10.5539/ijef.v11n2p165
Accepted: January 16, 2019

Online Published: January 20, 2019

URL: https://doi.org/10.5539/ijef.v11n2p165

\begin{abstract}
This empirical study is first of its nature to examine the weak-form of efficiency for unofficial foreign exchange market of Pakistan proxied by Japanese Yen (JPY/PKR), Swiss Franc (CHF/PKR), British Pound (GBP/PKR), and US Dollar (USD/PKR) exchange rates. For this we have employed Ljung Box Q-test, unit root tests including Dickey-Fuller (Dickey 1979), Augmented Dickey-Fuller (Dickey 1981) tests and Phillips and Perron (1988) test, Durbin Watson test, Runs-test, and Variance ratio test by using unofficial foreign exchange rate time series of Yen/PKR, CHF/PKR, GBP/PKR and USD/PKR from 1994M07 to 2001M06. Empirical results lead to the conclusion that the unofficial foreign exchange market of Pakistan is weak-form efficiency. The implications of this empirical research are of great importance for designing foreign exchange policy i.e. policy makers (be it accounting, export/import or public policy makers) are to consider fluctuations in unofficial foreign exchange rates while designing official foreign exchange rate policy of developing country like Pakistan. Further, policymakers can enhance the efficiency of official foreign exchange market by intervention subject to a widening of unofficial foreign exchange premium beyond a certain limit in developing countries like Pakistan.
\end{abstract}

Keywords: efficiency, black foreign exchange market, Pakistan, efficient market hypothesis, unit root tests, random walk hypothesis

\section{Introduction}

Efficient market hypothesis (EMH) was devised by Fama (1970) and since then has been the focus of academic, professionals, individual and institutional investors, and capital market participants due to its relevant implications in emerging and developed countries. It plays a key role in financial modeling for foreign exchange markets incorporating available information in current prices formulated by efficient markets (Fama, 1970) and in turn prohibiting market participants to earn abnormal profits by exploiting known information (Jensen, 1978). Market efficiency is further segregated into three forms with respect to the level of information embedded into prices namely, weak, semi-strong and strong form efficiency.

In the context of emerging markets, the existence of black (unofficial, parallel, kerb market) along with official foreign exchange markets is a well-known feature of many developing countries for several decades. Unofficial foreign exchange markets are results of government regulations and procedures that restrict direct access to the official foreign exchange markets mainly due to limited foreign reserves that cause imbalances in demand and supply to induce non-equilibrium exchange rates. Failure to control unofficial foreign rates has expanded the size of unofficial foreign exchange markets over time. The size and volume of transactions in unofficial foreign exchange markets of developing countries are not available because of its illegal nature (Dowla, 1995). In addition, other factors also cause the establishment of unofficial markets in developing countries such as worker remittances from the Middle East in case of Pakistan (Banuri, 1989) and drug-related activities in Colombia and Guyana (Thomas, 1989). Imposed penalties, tax implications and chances of getting caught also are one of the important determinants of unofficial foreign exchange markets Pitt (1984) and Jones and Roemer (1987). Emergence of unofficial markets can also be caused by controls on capital and foreign exchange, restrictions imposed on trade, and overvaluation of currency Agenor (1992). Contrary to it, arguments have been put forward by McDermott (1989) specifying that the authorities tend to accommodate rather than confront unofficial foreign exchange markets. The existence of unofficial foreign exchange market can affect the macroeconomic variables 
such as employment by raising the domestic availability of imported inputs and can cause of an increase in the supply of foreign currency to the central bank McDermott (1989). In addition, the unofficial foreign exchange rate has a significant impact on the economy of developing country like Pakistan Chaudhry and Butt (2014).

Number of studies have been undertaken to test efficient market hypothesis (EMH) of foreign exchange markets by employing different econometric techniques and find that official foreign exchange markets are efficient. (Coleman, 1990; Diebold et al., 1994; Lajaunie \& Naka, 1997; Korkmaz et al., 2009; Olmo \& Pilbeam, 2011; Ahmad et al., 2012). Other studies have concluded that foreign exchange markets are weak-form inefficient (Callen et al., 1989; Hakkio, 1986; Hansen \& Hodrick, 1980; MacDonald \& Taylor, 1989; Sephton \& Larsen, 1991; Pope \& Peel, 1991; Liu \& Maddala, 1992; Masih \& Masih, 1994; Karfakis \& Parikh, 1994; Barkoulas \& Baum, 1997; Zivot, 2000; Aroskar et al., 2004; Kühl, 2010; Çağlı \& Mandacı, 2013).

The pioneer study on the foreign exchange markets has been carried out by Gupta (1981) using weekly and monthly unofficial exchange rates of India, Korea and Taiwan where statistical results failed to reject efficient market hypothesis in the weak-form. Then, Culbertson (1989) investigated the weak-form efficiency of foreign exchange markets of 10 countries for the period of 1957 to 1983. Statistical results show that the current official exchange rates incorporate all relevant historical price information but such test have low power against alternatives Hakkio (1986). After that, Dowla (1995) examined weak-form efficiency of unofficial foreign exchange markets of thirteen developing countries and demonstrated that for most of the countries, included in the sample, unofficial foreign exchange markets are efficient.

Unofficial foreign exchange market proxied by four different exchange rates, Japanese Yen (JPY/PKR), Swiss Franc (CHF/PKR), British Pound (GBP/PKR) and US Dollar (USD/PKR) has existed in Pakistan throughout the period of the study 1990M06 to 2001M06 as per the criteria set by Ghei and Kamin (1996). Unofficial exchange rate of Pak-rupee was Rs. 32.02 per US\$ on June 30, 1994 which accelerated up to Rs. 66.55 per US\$ on June 30, 2001 after a depreciation of Rs. 34.53 or 107.84 percent. Further, a depreciation of 56.61 percent in CHF/PR, 65.52 percent in JPY/PKR, and 90.33 percent in GBP/PKR is noticed in the period of 1990M06 to 2001M06.

In the context of Pakistan, Ahmed et al. (2007) and Chaudhry et al. (2012) found official foreign exchange market weak-form of efficiency while Ahmed (2015) finds it weak-form inefficient. Consequently, these empirical findings present a puzzle, and to solve this puzzle the current study has been undertaken on the unofficial foreign exchange market of developing country like Pakistan by employing the most advanced econometric techniques.

The current study is different from the other studies as, for the first time, it examines the efficiency of the unofficial exchange rate of emerging economy like Pakistan. In addition, the planned study will investigate, for the first time, the efficiency of more than one unofficial foreign exchange rate of Pak-rupee versus Japanese Yen (JPY/PKR), Swiss Franc (CHF/PKR), British Pound (GBP/PKR) and US Dollar (USD/PKR), however, the previous studies have investigated only one official foreign exchange rate of Pak-rupee versus US dollar. Based on findings, implications recommend that policymakers should consider unofficial exchange rates while formulating efficient official exchange rate policy.

The key objective of this research is to investigate efficient market hypothesis (EMH) on unofficial foreign exchange market of Pakistan in the period from 1994M07 to 2001M06. The findings of the current study will assist the policymakers to use the information about unofficial foreign exchange rate to devise the official exchange rate policies, capital controls and trade restrictions. Rest of the empirical study has been divided into three sections, where Section 2 presents data and methodology, Section 3 is on results. Finally, Sections 4 concludes the study followed by the implications.

\section{Data and Methodology}

\subsection{Data Sources}

Monthly nominal unofficial foreign exchange rates of Pak-rupee versus Japanese Yen (JPY/PKR), Swiss Franc (CHF/PKR), British Pound (GBP/PKR), and US Dollar (USD/PKR) are used to estimate the efficiency of unofficial foreign exchange market of Pakistan. Monthly nominal unofficial foreign exchange rates for JPY/PKR, CHR/PKR, GBP/PKR and USD/PKR are obtained from the website of Khanani and Kalia (a local currency dealer in Pakistan) for the period from 1994M07 to 2001M06.

\subsection{Methodology}

To investigate the weak-form efficiency (WFE) of unofficial foreign exchange market serial correlation and unit root econometric methods are employed for random walk hypothesis (RWH). While RWH represents that current unofficial foreign exchange rates are independent of historical ones that lead to conclude that movement in prices 
is independently and identically distributed Fama (1970). Further, RWH represents that in case of weak-form efficiency the current prices fully reflect the information contained in the historical sequence of prices, and past prices have no statistical role to predict future unofficial foreign exchange rates and can be expressed as given below.

$$
E u_{t}=\mu+E u_{t-1}+\varepsilon_{t}
$$

Where, $\mathrm{Eu}_{\mathrm{t}}$ and $\mathrm{Eu}_{\mathrm{t}-1}$ are the current and one lagged unofficial foreign exchange rates, respectively, " $\mu$ " is drift, " $\varepsilon$ " is random error term, and "t" is time subscript. For estimation randomness of series is checked by testing either unit root does exist on levels, which indicates the weak-form efficiency. Moreover, econometric techniques are used to estimate serial independence of four unofficial foreign exchange rates that make unofficial foreign exchange market of Pakistan. In addition, specifically, weak-form efficiency of unofficial exchange market is tested under RWH by employing Ljung Box Q-test, unit root tests including Dickey-Fuller (Dickey, 1979), Augmented Dickey-Fuller (Dickey, 1981) tests and Phillips and Perron (1988) test, Durbin Watson test, Runs test, and Variance ratio test.

\section{a. $\quad$ Ljung Box Q-test / Autocorrelation Function Test (ACF)}

First, to identify random walk of exchange rates this study uses the Ljung Box (1979) Q- statistics with lags and the significance of this test will be checked with the help of p-values. The Q-statistic at lag " $k$ " is a test for the null hypothesis that there is no autocorrelation up to order " $\mathrm{k}$ " and is computed as:

$$
\mathrm{Q}_{\mathrm{LB}}=\mathrm{T}(\mathrm{T}+2) \sum_{\mathrm{i}=1}^{\mathrm{k}} \mathrm{r}_{\mathrm{j}}^{2} / \mathrm{T}-\mathrm{j}
$$

Where $r_{j}$ is the $j^{\text {th }}$ autocorrelation and " $T$ " is the number of observations. The Q-statistic is used as a test of whether the series is white noise or not. If the series is not based upon the results of ARIMA estimation, then under the null hypothesis, $\mathrm{Q}$ is asymptotically distributed as chi-squared $\left(x^{2}\right)$ with degrees of freedom equal to the number of autocorrelations.

\section{b. The Unit Root Tests for RWH}

Non-stationarity for RWH of unofficial foreign exchange rates series has been investigated by employing Dickey-Fuller (Dickey, 1981) and Augmented Dickey-Fuller (Dickey, 1979) unit root tests. A non-stationary series of integrated of order one I(1) indicates existence of unit root and does not follow deterministic process and difficult to predict and is random walk. Further, non-stationary time series of order I(1) implies unofficial foreign exchange market is weak-form efficient and vice versa.

First, Dickey-Fuller (1981) test is carried out by estimating the following equation,

$$
\Delta y_{t}=\mu+\gamma y_{t-1}+\varepsilon_{t}
$$

Where $\gamma=\rho-1$ and $\Delta$ is the first difference operator and test null and alternative hypotheses which are; $\mathrm{H}_{0}: \gamma=0$, and $\mathrm{H}_{1}: \gamma<0$. While it may appear that the test can be carried out by performing a $t$-test on the estimated $\gamma$, the t-statistic under the null hypothesis of a unit root does not have the conventional t-distribution. Dickey and Fuller (1979) showed that the distribution under the null hypothesis is non-standard, and simulated the critical values for selected sample sizes. MacKinnon (1991) has implemented a much larger set of simulations than those tabulated by Dickey and Fuller.

The Dickey-Fuller (1981) unit root test as described above is only valid if the series is an AR(1) process. If the series is correlated at higher order lags, the assumption of white noise disturbances is violated. The DF (1981) and ADF (1979) tests use different methods to control for higher-order serial correlation in the series. The ADF (1979) test makes a parametric correction for higher-order correlation by assuming that the y-series follow an AR(p) process. The ADF (1979) approach controls the higher-order correlation by adding lagged difference terms of the dependent variable $y$ to the right-hand side of the regression as given below:

$$
\Delta \mathrm{y}_{\mathrm{t}}=\mu+\gamma \mathrm{y}_{\mathrm{t}-1}+\delta_{1} \Delta \mathrm{y}_{\mathrm{t}-1}+\delta_{2} \Delta \mathrm{y}_{\mathrm{t}-2}+\ldots \ldots \ldots \ldots . . \delta_{\mathrm{p}-1} \Delta \mathrm{y}_{\mathrm{t}-\mathrm{p}+1}+\varepsilon_{\mathrm{t}}
$$

Then, this augmented specification is used to test $\mathrm{H}_{0}: \gamma=1$, and $\mathrm{H}_{1}: \gamma<0$, in this regression. An important result obtained is that the asymptotic distribution of the t-statistic is independent of the number of lagged at first differences included in the ADF regression.

Enders (1995) examines that when estimating weak-form efficiency of foreign exchange rate then Phillips and Perron (1988) test is more appropriate. Phillips and Perron (1988) modified Dickey-Fuller t-statistics with Z-statistics allowing further autocorrelation and conditional heteroscedasticity in error term of Dickey-Fuller 
regression and is expressed as given below.

$$
\tilde{\mathbf{t}}_{\beta}=\mathrm{t}_{\beta} \sqrt{\gamma_{0} / \mathrm{f}_{0}}-\frac{\mathbf{T}\left(\mathrm{f}_{0}-\gamma_{0}\right)(\operatorname{se}(\widehat{\beta}))}{2 \sqrt{\mathrm{f}_{0}} \cdot \mathrm{s}}
$$

Where $\tilde{t}_{\beta}$ is t-statistics and $\operatorname{se}(\widehat{\beta})$, "s" are standard error of $(\widehat{\beta})$ and test regression, respectively, and " $\gamma_{0}$ " is an estimator of random error-term and $f_{0}$ is an estimator or residual spectrum.

\section{c. Durbin-Watson Test}

The existence of significant positive or negative autocorrelation between current and the previous period foreign exchange rate indicates a certain trend in foreign exchange rate and no randomness does exist in time series. Further, a zero correlation between current and the previous foreign exchange rate leads to conclude that randomness does exist in foreign exchange rate series. To estimate the serial correlation between foreign exchange rates the following Durbin-Watson (1950) test has been applied.

$$
\mathrm{d}=\frac{\sum_{\mathrm{t}=2}^{\mathrm{T}}\left(\mathrm{Eu}_{\mathrm{t}}-\mathrm{Eu}_{\mathrm{t}-1}\right)^{2}}{\sum_{\mathrm{t}=1}^{\mathrm{T}} \mathrm{e}^{2}}
$$

Where " $T$ " is the number of observations, $\mathrm{Eu}_{\mathrm{t}}$ is the current unofficial foreign exchange rate and $\mathrm{Eu}_{\mathrm{t}-1}$ is the previous period unofficial foreign exchange rate. Further, "d" is Durbin-Watson statistics and always lies between 0 and $4(0<\mathrm{d}<4)$.

\section{d. Runs Test}

To estimate the unofficial foreign exchange market efficiency run test is used. For serial independence, and it tests the independence of successive runs. Further, a run is a sequence of successive positive or negative prices "+++++" or "-----" and the run length is a count of consecutive signs. Test statistic uses the run counts of both positive and negative runs. And for random walk actual number of runs " $r$ " and expected number of runs are same. For an unofficial foreign exchange rate series, $\mathrm{Eu}_{t}$ positive and negative runs are $\mathrm{N}_{+}$and $\mathrm{N}_{-}$, respectively, and the total number of runs is $\mathrm{N}=\mathrm{N}_{+}+\mathrm{N}_{-}$. For null $\left(\mathrm{H}_{\mathrm{o}}\right)$ the successive runs are independent and for large sample sizes, the test statistics follow normal distribution as given below.

$$
\mathrm{Z}=\frac{\mathrm{r}-\mu_{\mathrm{r}}}{\sigma_{\mathrm{r}}}: \mathrm{N}(0,1)
$$

Where $\mu_{r}$ and $\sigma_{r}$ are the sample mean and standard deviation and given below as;

$$
\begin{aligned}
& \mu_{\mathrm{r}}=\frac{2\left(\mathrm{~N}_{+}\right)\left(\mathrm{N}_{-}\right)}{\mathrm{N}}+1 \\
& \sigma_{\mathrm{r}}=\frac{\sqrt{2\left(\mathrm{~N}_{+}\right)\left(\mathrm{N}_{-}\right)\left(2\left(\mathrm{~N}_{+}\right)\left(\mathrm{N}_{-}\right)-\mathrm{N}\right)}}{\sqrt{\mathrm{N}^{2}(\mathrm{~N}-1)}}
\end{aligned}
$$

If the value of " $\mathrm{Z}$ " lies between -1.9 and $+1.96(-1.96<\mathrm{Z}$-value $<1.96)$ then it implies that value is significant and unofficial foreign exchange series follows random walk but if $Z$-value is less than -1.96 or greater than +1.96 then Z-value is insignificant which means unofficial foreign exchange rates are not following random walk.

\section{e. Variance Ratio Test}

To test the randomness of unofficial foreign exchange rate series the current study employs Variance Ratio test devised by Lo and Mckanlay (1988). For an unofficial foreign exchange rate series $\mathrm{Eu}_{\mathrm{t}}, \mathrm{t}=0,1,2, \ldots, \mathrm{nq}$ such that

$$
E u_{t}=\mu+E u_{t-1}+\varepsilon_{t}
$$

where, $E\left(\varepsilon_{t}\right)=0$ and $\operatorname{Cov}\left(\varepsilon_{t}, \varepsilon_{s}\right)=0 \quad t \neq s$

$$
=\sigma^{2} \mathrm{t}=\mathrm{s}
$$

Where $\mu$ is the drift parameter and $\varepsilon$ is error term and if $\mathrm{Eu}_{\mathrm{t}}$ follows random walk then the variance of $1^{\text {st }}$ difference $\mathrm{Eu}_{\mathrm{t}}-\mathrm{Eu}_{\mathrm{t}-1}$ is $1 / \mathrm{q}$ times variance of $\mathrm{Eu}_{\mathrm{t}}-\mathrm{Eu}_{\mathrm{t}-\mathrm{q}}$ or in other words variance ratio $\operatorname{VR}(\mathrm{q})$ of $\operatorname{Var}\left(\mathrm{Eu}_{\mathrm{t}}-\mathrm{Eu}_{\mathrm{t}-\mathrm{q}}\right) / \mathrm{q}$ to $\operatorname{Var}\left(\mathrm{Eu}_{\mathrm{t}}-\mathrm{Eu}_{\mathrm{t}-1}\right)$.

$$
\operatorname{VR}(q)=\frac{\operatorname{var}\left(E u_{t}-E u_{t-q}\right) / q}{\operatorname{var}\left(E u_{t}-E u_{t-q}\right)}=1 \text { Under } H_{o} \text { of random walk }
$$


Variance ratio test uses the $Z(q)$ test statistics for testing random walk hypothesis and follows an asymptotic normal distribution as given below.

$$
\text { Where, } \begin{aligned}
Z(q) & =(\operatorname{VR}(\mathrm{q})-1) \cdot\left[\widehat{\mathrm{S}}^{2}(\mathrm{q})\right]^{-1 / 2}: \mathrm{N}(\mathrm{O}, 1) \\
\mathrm{S}^{2}(\mathrm{q}) & =\frac{2(2 \mathrm{q}-1)(\mathrm{q}-1)}{3 \mathrm{qT}}
\end{aligned}
$$

And for heteroskedastic error terms test statistics $\stackrel{*}{Z}(q)$ is as follow.

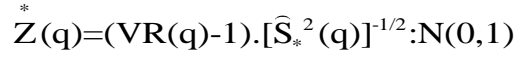

$$
\begin{aligned}
& \widehat{S}_{*}^{2}(q)=\sum_{j=1}^{q-1} \frac{[2(q-j)]^{2}}{q^{2}} \cdot \widehat{\delta}_{\text {本 }}
\end{aligned}
$$

Where, $\widehat{\delta}_{j}=\mathrm{nq}\left\{\sum_{\mathrm{k}=\mathrm{j}+1}^{\mathrm{nq}}\left(\mathrm{X}_{\mathrm{k}}-\mathrm{X}_{\mathrm{k}-1}-\hat{\mu}\right)^{2}\left(\mathrm{X}_{\mathrm{k}-\mathrm{j}}-\mathrm{X}_{\mathrm{k}-\mathrm{j}-1}-\hat{\mu}\right)^{2}\right\} *\left\{\sum_{\mathrm{k}=1}^{\mathrm{nq}}\left(\mathrm{X}_{\mathrm{k}}-\mathrm{X}_{\mathrm{k}-1}-\hat{\mu}\right)^{2}\right\}^{-2}$

\section{Results}

In this section, the efficiency of unofficial foreign exchange markets of Pak-rupee versus Swiss Franc, Japanese Yen, British Pound and US dollar is estimated by employing tests as given above in methodology and the results estimated from there are discussed. Statistical results obtained from Ljung-Box Q-test indicates that Q-statistics up to lag 12 is 625.64 for JPY/PKR, 333.58 for CHF/PKR, 12643.93 for GBP/PKR, and 12606.07 for USD/PKR are significant with associated p-values at one percent significance level as given in Table 1. From results, it is concluded that unofficial foreign rates series JPY/PKR, CHF/PKR, GBP/PKR, and USD/PKR are non-stationary and failed to reject random walk hypothesis and in turn find that unofficial foreign exchange market is weak-form efficient in Pakistan. Similarly, statistical results obtained from Ljung-Box Q-test indicate that Q-statistics up to lag 24 is 24768.46 for JPY/PKR, 24356.57 for CHF/PKR, 24830.18 for GBP/PKR, 24774.23 for USD/PKR, and are significant with p-values at one percent significance level as given in Table 1. From results, it is concluded that unofficial foreign rates series JPY/PKR, CHF/PKR, GBP/PKR, and USD/PKR are non-stationary, and failed to reject random walk hypothesis, and in turn, indicate that unofficial foreign exchange

\begin{tabular}{|c|c|c|c|c|}
\hline & \multicolumn{2}{|c|}{ Q12 } & \multicolumn{2}{|c|}{ Q24 } \\
\hline & $\mathrm{Q}^{*} 12$ & Prob. & $\mathrm{Q} * 24$ & Prob. \\
\hline JPY/PKR & 625.64 & 0.000 & 24768.46 & 0.000 \\
\hline CHF/PKR & 333.58 & 0.000 & 24356.57 & 0.000 \\
\hline GBP/PKR & 12643.93 & 0.000 & 24830.18 & 0.000 \\
\hline USD/PKR & 12606.07 & 0.000 & 24774.23 & 0.000 \\
\hline
\end{tabular}
market of Pakistan is weak-form efficient.

Table 1. Q-statistics up to $12 \& 24$ lags for unofficial pak-rupee foreign exchange rates

Prior to employee unit root tests, to estimate the efficiency of unofficial foreign exchange rate time series of Pak-rupee against major currencies, optimal lag length is computed by employing vector autoregressive (VAR) selection criteria. Results indicate an optimal lag length of 12 as per Akaike Information Criterion (AIC) and results are given in Appendix I. To investigate weak-form efficiency of unofficial foreign exchange market of Pakistan applied unit root tests, and results obtained from DF (1981), ADF (1979) and PP (1988) tests at 5 percent significance levels are given below in Panel-1, Panell-2 and Panel-3, respectively, in Table 2. Results obtained from unit root tests indicate that null hypothesis of unit root at levels with intercept and 12 lags based on AIC cannot be rejected for unofficial foreign exchange rates included JPY/PKR, CHF/PKR, GBP/PKR, and USD/PKR. This indicates that time series are non-stationary, and failed to reject null of random walk hypothesis in all unofficial foreign exchange rates which in turn leads to conclude that unofficial foreign exchange market of Pakistan is weak-form efficient. Findings from these results also indicate that unofficial foreign exchange rates cannot be forecasted based on historical rate that in turn prohibits consistent systematic abnormal profit earnings by market participants. 
Table 2. Unit root tests for unofficial pak-rupee foreign exchange rates

\begin{tabular}{|c|c|c|c|c|}
\hline \multicolumn{5}{|c|}{ Panel-1: DF Unit Root Test for Parallel Spot Rates of Pak-Rupee } \\
\hline & \multicolumn{2}{|c|}{ In Levels } & \multicolumn{2}{|c|}{ In First Difference } \\
\hline Currency & t-statistic & Prob. & t-statistic & Prob. \\
\hline JPY/PKR & -1.893624 & 0.0618 & -8.675489 & 0.000 \\
\hline $\mathrm{CHF} / \mathrm{PKR}$ & -1.067344 & 0.289000 & -11.16897 & 0.000 \\
\hline GBP/PKR & -1.007394 & 0.3167 & -7.978337 & 0.000 \\
\hline \multirow{2}{*}{$\begin{array}{c}\text { USD/PKR } \\
\text { cv at } 5 \% \text { Significant Level }\end{array}$} & 0.191660 & 0.8485 & -7.561405 & 0.000 \\
\hline & -2.8963 & & -2.8967 & \\
\hline \multicolumn{5}{|c|}{ Panel-2: ADF Unit Root Test for Parallel Spot Rates of Pak-Rupee } \\
\hline & \multicolumn{2}{|c|}{ In Levels } & \multicolumn{2}{|c|}{ In First Difference } \\
\hline Currency & t-statistic & Prob. & t-statistic & Prob. \\
\hline JPY/PKR & -1.961697 & 0.0533 & -5.019662 & 0.000 \\
\hline $\mathrm{CHF} / \mathrm{PKR}$ & -0.777193 & 0.439400 & -6.765631 & 0.000 \\
\hline GBP/PKR & -1.130111 & 0.2618 & -5.032543 & 0.000 \\
\hline \multirow{2}{*}{$\begin{array}{c}\text { USD/PKR } \\
\mathrm{cV} \text { at } 5 \% \text { Significant Level }\end{array}$} & -0.082612 & 0.9344 & -5.071228 & 0.000 \\
\hline & -2.8967 & & -2.8972 & \\
\hline \multicolumn{5}{|c|}{ Panel-3: PP Unit Root Test for Parallel Spot Rates of Pak-Rupee } \\
\hline & \multicolumn{2}{|c|}{ In Levels } & \multicolumn{2}{|c|}{ In First Difference } \\
\hline & t-statistic & Prob. & t-statistic & Prob. \\
\hline JPY/PKR & -2.792351 & 0.2043 & -12.96196 & 0.000 \\
\hline $\mathrm{CHF} / \mathrm{PKR}$ & -2.485131 & 0.3346 & -8.639486 & 0.000 \\
\hline GBP/PKR & -2.103457 & 0.5361 & -7.995252 & 0.000 \\
\hline USD/PKR & -2.658063 & 0.2566 & -7.555422 & 0.000 \\
\hline
\end{tabular}

Results from DF (1981), ADF (1979) and PP (1988) also indicate that unofficial foreign exchange rates such as JPY/PKR, CHF/PKR, GBP/PKR, and USD/PKR are stationary at the first difference or in other words integrated of order one $\mathrm{I}(1)$.

Estimated Durbin-Watson statistics for JPY/PKR (=2.391886), CHF/PKR (=1.895170), GBP/PKR (=1.669805) and USD/PKR $(=1.759439)$ are for four currencies are positive and indicate that each monthly foreign exchange rate time series has no autocorrelation or in other words failed to reject weak-form efficient market hypothesis as given in Table 3. This leads to conclude that unofficial foreign exchange market of Pakistan is weak-form efficient.

Table 3. Durbin-watson test for unofficial pak-rupee foreign exchange rates

\begin{tabular}{cc}
\hline Currencies & Estimated Durbin-Watson Statistic \\
\hline JPY/PKR & 2.391886 \\
CHF/PKR & 1.895170 \\
GBP/PKR & 1.669805 \\
USD/PKR & 1.759439 \\
\hline
\end{tabular}

Statistical results for variance ratio VR(j) is obtained by employing Lo and MacKinaly (1988) test and are reported in Table 4. Results obtained from Lo and Mackinlay (1988) variance ratio (VR) test for JPY/PKR, CHF/PKR, GBP/PKR, and USD/PKR exchange rates indicate that none of the test-statistics for homoscedastic increments $Z(j)$ and heteroscedasticity robust test $Z *(j)$ for investment horizons $j=2,4,8$ and 16 is insignificant. Therefore, the null of random walk hypothesis cannot be rejected for JPY/PKR, CHF/PKR, GBP/PKR, and USD/PKR exchange rates. This leads to conclude that JPY/PKR, CHF/PKR, GBP/PKR, and USD/PKR exchange rates market is weak-form efficient.

Table 4. Estimated results for variance ratio for different time horizons

\begin{tabular}{ccccc}
\hline JPY/PKR: Results of Variance Ratio (VR) Test & \multicolumn{3}{c}{} \\
\hline & $\mathrm{j}=2$ & $\mathrm{j}=4$ & $\mathrm{j}=8$ & $\mathrm{j}=16$ \\
$\mathrm{VR}(\mathrm{j})$ & 0.793322 & 0.706679 & 0.638669 & 0.468839 \\
$\mathrm{Z}(\mathrm{j})$ & -1.88292 & -1.42839 & -1.33163 & -1.09937 \\
$\mathrm{Z} *(\mathrm{j})$ & -1.37583 & -1.11261 & -1.06852 & -0.98782 \\
\hline
\end{tabular}




\begin{tabular}{|c|c|c|c|c|}
\hline \multicolumn{5}{|c|}{ CHF/PKR: Results of Variance Ratio (VR) Test } \\
\hline & $\mathrm{j}=2$ & $\mathrm{j}=4$ & $\mathrm{j}=8$ & $\mathrm{j}=16$ \\
\hline $\operatorname{VR}(\mathrm{j})$ & 1.051525 & 1.269015 & 1.233971 & 1.016314 \\
\hline $\mathrm{Z}(\mathrm{j})$ & 0.469418 & 1.310032 & 0.862265 & 0.033765 \\
\hline$Z^{*}(\mathrm{j})$ & 0.445665 & 1.196148 & 0.780559 & 0.031941 \\
\hline \multicolumn{5}{|c|}{ GBP/PKR: Results of Variance Ratio (VR) Test } \\
\hline & $\mathrm{j}=2$ & $\mathrm{j}=4$ & $\mathrm{j}=8$ & $\mathrm{j}=16$ \\
\hline $\operatorname{VR}(\mathrm{j})$ & 1.141247 & 1.347235 & 1.270844 & 0.927821 \\
\hline $\mathrm{Z}(\mathrm{j})$ & 1.286821 & 1.690944 & 0.998154 & -0.14939 \\
\hline $\mathrm{Z}^{*}(\mathrm{j})$ & 1.508296 & 1.378928 & 0.789506 & -0.1243 \\
\hline \multicolumn{5}{|c|}{ USD/PKR: Results of Variance Ratio (VR) Test } \\
\hline & $\mathrm{j}=2$ & $j=4$ & $\mathrm{j}=8$ & $j=16$ \\
\hline $\operatorname{VR}(\mathrm{j})$ & 1.194302 & 1.370945 & 1.248604 & 0.82586 \\
\hline $\mathrm{Z}(\mathrm{j})$ & 1.770175 & 1.806403 & 0.916192 & -0.36043 \\
\hline$Z^{*}(\mathrm{j})$ & 1.081773 & 1.088433 & 0.550466 & -0.25359 \\
\hline
\end{tabular}

Note. Variance Ratio statistics VR(j) is given for investment horizons $\mathrm{j}=2,4,8,16, \mathrm{Z}(\mathrm{j})$ is variance statistics for homoscedastic increment, and $\mathrm{Z}^{*}(\mathrm{j})$ is heteroskedastic $\mathrm{z}$-statistics for robust test. * indicates rejection of null of random walk hypothesis at $1 \%$ significance level, whereas under the null of random walk, variance ratio is expected to equal to one.

\section{Conclusion}

The current empirical study is first of its nature to examine the weak-form efficiency of unofficial foreign exchange market of Pakistan proxied by Japanese Yen (JPY/PKR), Swiss Franc (CHF/PKR), British Pound (GBP/PKR), and US Dollar (USD/PKR) exchange rates. For this employed Ljung Box Q-test, unit root tests including Dickey-Fuller (Dickey 1979), Augmented Dickey-Fuller (Dickey 1981) tests and Phillips and Perron (1988) test, Durbin Watson test, Run-test, and Variance ratio test by using by using unofficial foreign exchange rate time series of Yen/PKR, CHF/PKR, GBP/PKR and USD/PKR from 1994M07 to 2001M06. Empirical results lead to conclude that unofficial foreign exchange market of Pakistan is weak-form efficient. These findings are in line with Coleman. (1990); Diebold et al. (1994); Lajaunie and Naka (1997); Wu and Chen (1998); Korkmaz et al. (2009); Pilbeam and Olmo, (2011); Ahmad et al. (2012), and differ from those of Callen et al. (1989); Hakkio, (1986); Hansen and Hodrick (1980); MacDonald and Taylor (1989); Sephton and Larsen (1991); Pope and Peel (1991); Liu and Maddala (1992); Masih and Masih (1994); Karfakis and Parikh (1994); Barkoulas and Baum (1997); Zivot (2000); Aroskar et al. (2004); Kühl (2010); Çağlı and Mandacı (2013).

The implications of this empirical research are of great importance while designing foreign exchange policy i.e. policy makers are required to consider fluctuations in unofficial foreign exchange rates while designing official foreign exchange rate policy of developing country like Pakistan. Further, policymakers can enhance the efficiency of official foreign exchange market by intervention subject to a widening of unofficial foreign exchange premium beyond a certain limit in developing countries like Pakistan. Empirical research on the efficiency of the unofficial foreign exchange markets can be extended to other developing countries included China, Russia, East-Europe, Turkey, and South-American countries. Comparative research can be undertaken on the efficiency of the official and unofficial foreign exchange markets in developing countries. This study could be further extended to provide new insights for setting public policy in the realm of accounting, education, health, derivative markets and international debt management.

\section{References}

Agenor, R. P. (1992). Parallel Currency Markets in Developing Countries: Theory, Evidence, and Policy Implications. Essays in International Finance, (188).

Ahmad, R., Rhee, S. G., \& Wong, Y. M. (2012). Foreign exchange market efficiency under recent crises: Asia-Pacific focus. Journal of International Money and Finance, 31(6), 1574-1592. https://doi.org/10.1016/j.jimonfin.2012.02.016

Ahmed, K. M., Ashraf, S., \& Ahmed, S. (2007). Efficiency of foreign exchange markets: Evidence from south Asian countries. Indian Journal of Economics, 88(3), 17-33.

Ahmed, Z. I. (2015). The Efficiency of Exchange Rate Market: A Case Study on Pakistan. International Journal of Economics, Finance and Management Sciences, 3(2), 125-137. https://doi.org/10.11648/j.ijefm.20150302.17 
Aroskar, R., Sarkar, S. K., \& Peggy, E. S. (2004). European foreign exchange market efficiency: Evidence based on crisis and non-crisis periods. International Review of Financial Analysis, 13(3), 333-347. https://doi.org/10.1016/j.irfa.2004.02.011

Banuri, T. (1989). Black Markets, Openness, and Central Bank Autonomy. World Institute for Development Economics Research, Working Paper (62), Helsinki (Finland).

Barkoulas, J., \& Baum, C. F. (1997). A re-examination of the fragility of evidence from cointegration-based tests of foreign exchange market efficiency. Applied Financial Economics, 7, 635-643. https://doi.org/10.1080/758533855

Çağl1, E. Ç., \& Mandacı, P. E. (2013). The long-run relationship between the spot and futures markets under multiple regime-shifts: Evidence from Turkish derivatives exchange. Expert Systems with Applications, 40(10), 4206-4212. https://doi.org/10.1016/j.eswa.2013.01.026

Callen, J. I., Chan, M. W. L., \& Kwan, C. C. Y. (1989). Spot and forward exchange rates: A causality analysis. Journal of Business Finance and Accounting, 16(1), 105-118. https://doi.org/10.1111/j.1468-5957.1989.tb00007.x

Chaudhry, A. F., \& Butt, A. R. (2014). Comparative Impact of Unofficial and Official Exchange Rates on the Economy of Pakistan. World Review of Business Research, 4(3), 181-195.

Chaudhry, S. A., \& Javid, A. Y. (2012). Efficiency of the foreign exchange markets of South Asian countries. PIDE Working Paper, 2012(82).

Coleman, M. (1990). Cointegration-based tests of daily foreign exchange market efficiency. Economics Letters, 32(1), 53-59. https://doi.org/10.1016/0165-1765(90)90049-7

Culbertson, W. P. (1989). Empirical regularities in black markets for currency. World Development, 17(12), 1907-1919. https://doi.org/10.1016/0305-750X(89)90270-2

Dickey, D. A., \& Fuller, W. A. (1979). Distribution of the Estimators for Autoregressive Time Series with a Unit Root. Journal of the American Statistical Association, (74), 427-431.

Dickey, D. A., \& Fuller, W. A. (1981). The likelihood Ratio Statistics for Autoregressive Time Series with a Unit Root. Econometrica, (49), 57-72. https://doi.org/10.2307/1912517

Diebold, F. X., Gardeazabal, J., \& Yilmaz, K. (1994). On cointegration and exchange rate dynamics. The Journal of Finance, 49(2), 727-735. https://doi.org/10.1111/j.1540-6261.1994.tb05160.x

Dowla, A. (1995). Efficiency of The Black Market For Foreign Exchange. International Economic Journal, 9(2), 89-100.

Durbin, J., \& Watson, G. S. (1950). Testing for Serial Correlation in Least Squares Regression. Biometrika, 37(1950), 409-428.

Enders, W. (1995). Applied econometric time series. New York: John Wiley \& Sons, Inc.

Fama, E. (1970). Efficient Capital Markets: A Review of Theory and Empirical Work. Journal of Finance, (25), 383-417. https://doi.org/10.2307/2325486

Ghei, N., \& Kamin, S. B. (1996). The use of parallel market rate as a guide to setting the official exchange rate. Board of Governors of the Federal Reserve System. International Finance Discussion Papers No. 564.

Gupta, S. (1981). A Note of the Efficiency of Black Markets in Foreign Currencies. The Journal of Finance, 36(3), 705-710. https://doi.org/10.1111/j.1540-6261.1981.tb00655.x

Hakkio, C. (1986). Does the Exchange Rate Follow a Random Walk? A Monte Carlo Study of Four Tests for Random Walk. Journal of International Money and Finance, 221-230. https://doi.org/10.1016/0261-5606(86)90043-4

Hansen, L. P., \& Hodrick, R. J.(1980). Forward exchange rates as optimal predictors of future spot rates: An econometric analysis. Journal of Political Economy, 88(October), 829-853. https://doi.org/10.1086/260910

Jensen, M. (1978). Some anomalous evidence regarding market efficiency.

Jones, C., \&Roemer, M. (1987). Microeconomics of Price Controls: A Reexamination. Development Discussion Paper No. 242, Harvard Institute for International Development (Cambridge).

Karfakis, C. I., \& Parikh, A. (1994). Exchange rate convergence and market efficiency. Applied Financial Economics, 4, 93-98. https://doi.org/10.1080/758523953 
Khanani and Kalia International (Pvt.) Ltd. Retrieved October 10, 2002 from http://www.kalpoint.com/

Korkmaz, T., Cevik, E. I., \& Özataç, N. (2009). Testing for long memory in ISE using ARFIMA-FIGARCH model and structural break test.

Kühl, M. (2010). Bivariate cointegration of major exchange rates, cross-market efficiency and the introduction of the Euro. Journal of Economics and Business, 62, 1-19. https://doi.org/10.1016/j.jeconbus.2009.07.002

Lajaunie, J. P., \& Naka, A. (1997). Re-examining Cointegration, Unit Roots and Efficiency in Foreign Exchange Rates. Journal of Business Finance \& Accounting, 24(3), 363-374. https://doi.org/10.1111/1468-5957.00109

Liu, P. C., \& Maddala, G. S. (1992). Rationality of survey data and tests for market efficiency in the foreign exchange markets. Journal of International Money and Finance, 11(August), 366-381. https://doi.org/10.1016/0261-5606(92)90030-2

Ljung, G., \& Box, G. (1979). On a Measure of Lack of Fit in Time Series Models. Biometrika, (66), 265-270. https://doi.org/10.1093/biomet/66.2.265

Lo A.W, MacKinlay A.C. (1988) Stock market prices do not follow random walks: Evidence from asimple specification test. Rev Finan Stud., 1(1), 41-66. https://doi.org/10.1093/rfs/1.1.41

MacDonald, R., \& Taylor, M. P. (1989). Foreign exchange market efficiency and cointegration. Economics Letters, 29(1), 63-67. https://doi.org/10.1016/0165-1765(89)90174-2

MacKinnon, J. G. (1991). Critical Values for Cointegration Tests. In R. F. Engle, \& C. W. J. Granger (Eds.), Chapter 13 in Long-run Economic Relationships: Readings in Cointegration. Oxford University Press.

Masih, A. M. M., \& Masih, R. (1994). On the robustness of cointegration tests of the market efficiency hypothesis: Evidence from six European foreign exchange markets. Economia Internazionale.

McDermott, J. H. (1989). Foreign-exchange rationing and employment in industrializing countries. Journal of International Economics, 27(3-4), 245-264. https://doi.org/10.1016/0022-1996(89)90054-8

Olmo, J., \& Pilbeam, K. (2011). Uncovered interest parity and the efficiency of the foreign exchange market: a re-examination of the evidence. International Journal of Finance \& Economics, 16(2), 189-204. https://doi.org/10.1002/ijfe.429

Phillips, P. C. B., \& Perron, P. (1988). Testing for a unit root in time series regression. Biometrika, 75, 335-346. https://doi.org/10.1093/biomet/75.2.335

Pitt, M. (1984). Smuggling and Black Market for Foreign Exchange. Journal of International Economics, (16), 243-257. https://doi.org/10.1016/S0022-1996(84)80003-3

Pope, P. F., \& Peel, D. A. (1991). Forward foreign exchange rates and risk premia-a reappraisal. Journal of International Money and Finance, 10(3), 443-456. https://doi.org/10.1016/0261-5606(91)90021-B

Sephton, P., \& Larsen, H. (1991). Tests of exchange market efficiency: Fragile evidence from cointegration tests. Journal of International Money and Finance, 10(4), 561-570. https://doi.org/10.1016/0261-5606(91)90007-7

Taylor, M. P. (1989). Expectations, risk and uncertainty in the foreign exchange markets: Some results based on survey data. Journal of Manchester School of Economics, 57, 142-153. https://doi.org/10.1111/j.1467-9957.1989.tb00807.x

Thomas, C. Y. (1989). Foreign Currency Black Markets: Lessons from Guyana. Unpublished Manuscript, Kingston, Jamaica.

Wu, J. L., \& Chen, S. L. (1998). Foreign exchange market efficiency revisited. Journal of International Money and Finance, 17, 831-838. https://doi.org/10.1016/S0261-5606(98)00028-X

Zivot, E. (2000). Cointegration and forward and spot exchange rate regressions. Journal of International Money and Finance, 19(6), 785-812. https://doi.org/10.1016/S0261-5606(00)00031-0 


\section{Appendix I}

Var Lag Selection Using Akaike Information Criteria (AIC)

\begin{tabular}{cccllll}
\hline Lag & LogL & LR & FPE & AIC & SC & HQ \\
\hline 0 & -485.0326 & NA & 9.325357 & 13.58424 & 13.71072 & 13.63459 \\
1 & -160.0288 & 604.8681 & $0.001747^{*}$ & 5.000800 & $5.633208^{*}$ & $5.252564^{*}$ \\
2 & -149.4116 & 18.58017 & 0.002038 & 5.150322 & 6.288655 & 5.603495 \\
3 & -140.8050 & 14.10527 & 0.002529 & 5.355694 & 6.999953 & 6.010278 \\
4 & -129.3673 & 17.47430 & 0.002930 & 5.482424 & 7.632608 & 6.338419 \\
5 & -114.0699 & 21.67131 & 0.003089 & 5.501940 & 8.158051 & 6.559346 \\
6 & -103.1559 & 14.24883 & 0.003743 & 5.643218 & 8.805255 & 6.902034 \\
7 & -83.57374 & 23.38976 & 0.003645 & 5.543715 & 9.211677 & 7.003941 \\
8 & -53.52712 & $32.55050^{*}$ & 0.002731 & 5.153531 & 9.327419 & 6.815168 \\
9 & -40.90005 & 12.27632 & 0.003443 & 5.247224 & 9.927037 & 7.110271 \\
10 & -12.01680 & 24.87169 & 0.002897 & 4.889355 & 10.07509 & 6.953814 \\
11 & -6.763188 & 3.940206 & 0.005000 & 5.187866 & 10.87953 & 7.453735 \\
12 & 22.11227 & 18.44821 & 0.004871 & $\mathbf{4 . 8 3 0 2 1 5 *}$ & 11.02781 & 7.297494 \\
\hline
\end{tabular}

* indicates lag order selected by the criterion

LR: sequential modified LR test statistic (each test at 5\% level)

FPE: Final prediction error

AIC: Akaike information criterion

SC: Schwarz information criterion

HQ: Hannan-Quinn information criterion

\section{Copyrights}

Copyright for this article is retained by the author(s), with first publication rights granted to the journal.

This is an open-access article distributed under the terms and conditions of the Creative Commons Attribution license (http://creativecommons.org/licenses/by/4.0/). 